\title{
Intercultural and lifelong learning based on educational drama ${ }^{1}$
}

\author{
Propositions for Multidimensional Research Projects
}

\section{Alkistis Kondoyianni, Antonis Lenakakis, Nikos Tsiotsos}

1. In this article the phrase educational drama alternates with pedagogical theatre, due to our German references where the compound Theaterpädagogik is used, hence also our coining of the anglicized adjective theatropedagogical (see 5.2 and Concluding Note), both stems of which are rooted in the Greek language.

\begin{abstract}
This paper is an attempt to propose multidimensional research projects and therefore it is addressed to researchers and theatre/drama-pedagogues. Our principal aim of this paper is to suggest ways to investigate the role of drama both as a methodology in itself in the fields of education and lifelong learning, and as a means suitable for implementation in many other arenas. Our focus on alternative dramatic forms such as puppetry, dramatised narration and creative writing in role, enhances the implication of a rather broad spectrum of prospective participant groups beyond students, such as immigrants, prison convicts and the elderly. We also aim at the facilitation of the involvement of all people who seek ways of improving their professional competence and who could benefit from the implementation of drama techniques in workplaces such as museums, public libraries, and in some sectors of the tourism industry. We firmly believe that the role of educational drama deserves to be consolidated in many areas of social science and social work.
\end{abstract}

\section{Introduction}

The research proposals that we suggest in this paper concern Greek and international standards and they are based: (i) on the propositional texts of the European Union and of various international organizations, (ii) on lifelong learning researchers findings and (iii) on Studies concerning the role of drama and the arts in education internationally. Furthermore, our research proposals are accompanied with suggested actions (see Chapter 5). Through these suggested actions, we argue that a variety of social issues could be effectively handled and investigated through the practice of drama. 
Drama has been embraced at all levels in the fields of education and lifelong learning, thanks to its capacity to promote intelligent feeling, ${ }^{2}$ and to generally contribute to the aesthetic education of children and young people (see Hentschel 2010). It does this largely through its capacity to sustain suspension of disbelief ${ }^{3}$. Besides, it has been proven capable to enhance learning at all levels of the curriculum, ${ }^{4}$ rendering it popular among both educators and students. The practice of drama gives students the opportunity to actively participate in imagined worlds involving a broad spectrum of vocations and knowledge fields, actually helping them rehearse their responses to situations they will be faced with in their adult lives. Notably, drama courses have an established place in the curricula of academic departments not only of education or the humanities, but also of natural sciences and technology (see Fines \& Verrier 1974, Adiguzel 2008, Dörger \& Nickel 2005).

In an era when sociopolitical and economic conditions are reshaping Europe and the whole world, recent insights in the field of human sciences bring forward the need for groundbreaking educational policy-making. In this socio-political and educational context we consider the arts and mainly drama as an especially powerful subject and one closely connected to our rich European cultural inheritance.

\section{Educational Drama and Pedagogical Theatre}

To make the necessary distinctions between these two pairs of terms without any etymological elaborations, let us succinctly define "drama" as a scenario

\footnotetext{
2 This should not be confused with the term "emotional intelligence" as defined by Goleman (2004). It does not refer to a subject's social skills or capacity to emotionally adapt to everchanging life conditions. Rather, it is concerned with the "feeling-ideas" (Gefühlsideen) and the subject-reflexive action (present in all works of art) that renders possible the communication of ideas through art (see Langer 1954; Witkin 1974; Ross 1978 1984; Hentschel 2010).

3 The term "suspension of disbelief" was coined by Samuel Taylor Coleridge in his Biographia Literaria in 1907, in order to stress the semblance of truth that a writer infuses into a work of literature, so that the reader would suspend judgment concerning the implausibility of the narrative, while accepting the fictional characters and actions as temporarily "real". The term has been widely used by the pioneers of educational drama, and most notably by Heathcote and her devotees, to stress the importance of drama's fictional reality created in the classroom capable to bring about action and interaction among students-characters who also experience the created condition they are asked to act in as temporarily "real". In the words of O’Toole (1992: 50), "Drama in education and theatre in education are two more such genres. They take place in settings which actively mediate against the ready suspension of disbelief; schools have very specialised purposes, and very strong messages of reinforcement for them - many of the practices of schooling are specifically designed as focussing devices for those purposes."

4 "A problem with many curriculum guides" says Taylor (2000: 7, our emphasis), "is that they present objectives and content in a static and lifeless manner seemingly ignoring the fact that people have to make curriculum happen. Any good drama teacher knows that curriculum is a lived experience; it is negotiated with colleagues and students - a fallible event dependent upon the abilities, moods and backgrounds of those who construct it." See also Lenakakis 2004 on the role of the drama teacher in the formation of a "living curriculum", and Domkowsky 2011 on the multi-dimensionality of learning promoted by drama.
} 
and "theatre" as its enactment. This study of ours, then, focuses on the establishment of and the cooperation between different scientific, social and cultural groups on the one hand, and the combinations among different forms of artistic expression and creative activities on the other. In this venture we place particular emphasis on the role of drama and the arts, since these universal symbolic activities have developed common forms and patterns capable to summarise human creativity and inventiveness in response to individual and social needs. ${ }^{5}$ Especially with regard to theatre, the commonalities between various countries, ethnic groups and cultures are particularly evident, both diachronically and synchronically: from the rituals of prehistoric African societies to the modern Olympic opening ceremonies; from the ancient Greek drama to the Kabuki dance theatre; from Boal's Theatre of the Oppressed to the Forum Theatre in Australia; from Brecht's epic theatre in Germany to theatre forms as diverse as those of Pakistan or New York (see Fischer-Lichte 1999,

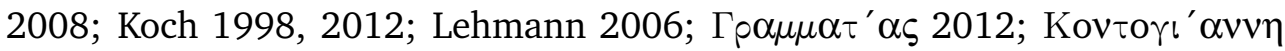
2008). These commonalities are owed to the fact that the practice of theatre helps people deeply understand each other, regardless of their physical, ethnic and cultural differences. Indeed, the expressive media of drama and theatre have the capacity of condensing real-life social stories and universal binary opposites - as put forward by Levi-Strauss (1963) - such as realities and dreams, loneliness and community, happiness and despair, blessings and sufferings. The immense stage of the world is represented with props and partial sceneries of rooms and houses, offices and worksites, hotels and factories, streets and local communities, villages, cities, airports, mountains, deserts, a majestic theatrical universe transcending borders, language, race and religion.

Thus drama and theatre become hubs for bringing all participants together as members of a global community, by managing to transform everyday realities into everyday dramas (Pinkert 2005, O’Toole \& Daneman 1996), dramas which imbue peoples' lives with a sense of metaphor and render them more meaningful (Boal 1993, 1996, Pammenter \& Mavrokordatos 2003, O’Toole \& Daneman 1996, Somers 2006).

Drama and theatre are quintessential promoters of the communication of ideas and behavioural patterns in our civilization; they assist us in our attempts to play out basic roles which help us form our own personal identities, ideals and social values. ${ }^{6}$ They serve as blueprints for shaping our social lives, in turn setting in motion the creation of political frames of mind, which are not created randomly; they are created as a result of the sedulous examination in the theatre laboratory which is a social laboratory; a laboratory that provides us with a more precise and tangible context. ${ }^{7}$ The lens of theatre helps us better envisage and apprehend human behaviour. And it is, in fact, this realization

\footnotetext{
${ }^{6}$ For an attempt to denote the role of drama as a critical pedagogy agent, see Doyle (1993).

7 "My own view is that, limited as this learning experience may be in terms of an art form, it would be perverse for a drama teacher to exclude it on these grounds. It does, after all, give practice in the skill that is basic to all kinds of acting, which is: an ability to engage with something outside oneself using an 'as if' mental set to activate, sustain or intensify that engagement." (Bolton 1982: 137)
} 
that renders us capable of criticism and revolt, imbuing us with the will to either alter our unbearable realities or abolish them from our personal or social landscapes.

Drama and the arts are most effective tools for sensing and making sense of the world. They function not only through seeking the natural and social laws governing human action, but they also create imageries providing a holistic access to natural and social phenomena. ${ }^{8}$ They enrich the human mind so that we can transcend and expand our conceptions of life. Theatrical processes help us perceive the world as a much broader and richer entity than any small social sphere, creating for the spectators transitional phenomena, dynamic areas of experience through which internal and external realities come together in a controllable manner. ${ }^{9}$ According to Winnicott $(1992,2005)$, transitional phenomena imbue human existence with valuable insights and offer meaningful outlets for people seeking answers to deep questions. The heart of the drama workshop are the students who interact with their own enacted characters in a symbiosis of the ego with the other in the safety of the role-play.

A more analytical eye on the procedures taking place in a drama workshop (see also Lenakakis 2004) reveals the central importance of the role-players as both conscious agents and objects of the action. The formation of a subjective imaginative reality presupposes an interrelation of the role-player with the character as an archetypical figure as well as with the fictional context in which this character acts.

In the same context, the regularity of real life is transformed into the play's own peculiar regularity. These two realities relate to each other in a dynamic, critical and at times subversive relationship, where the life history and the whole personal repertoire of the actor-person becomes activated in a holistic, yet ineffable manner.

Nevertheless, while the personal play ${ }^{10}$ involves the construction of another

\footnotetext{
8 For an account of the holistic vision of the arts and its role in children's thinking, see Reid 1986 and Abbs 1979 2003. See also Schiller's (2004) famous maxim about the wholedimensional activation of man in play: "man only plays when in the full meaning of the word he is a man, and he is only completely a man when he plays" (Letter XV).

${ }^{9}$ For an interesting account of drama as a transitional experience see Schechner 1988 and also Turner 1974 1978. The former creates a combination of Winnicott's account of the transitional phenomena and Victor Turner's view of the transitional nature of the social rituals, in an attempt to establish performance as an indispensible factor of social existence. To reiterate one of Bruner's (1996) views, culture shapes our cognition and provides us with the basic tools with which we not only construct our reality but we also realise our potentials and the best of ourselves. Knowing our cultural milieu enables us to expand our understanding of the worlds we inhabit whilst contributing to the development of memory, imagination and language (Olson Torrance 1999). Our cultural heritage and more specifically mythology and theatre, ancient Greek philosophy and literature, painting, sculpture, music, popular culture and -tradition contain dynamic cognitive forms which comprise unique achievements of the human spirit. From these respects and in relation to Luria's (1978) psychosocial theory and to Vygotsky's (1978 2012) sociocultural conception of human cognition, we are able to stress the importance of the involvement of the arts and drama in the context of education, as it comes about in accordance with the recent developments of psychology, education and technology.

10 A thorough account of the personal play of the child can be found in Slade's (1953)
} 
reality ${ }^{11}$ that obeys to the personal conventions of the actor, the materials for the construction of such a reality are still only symbolic interpretations of the actors' real experiences. Thus, the symbolic play activities can offer a fruitful context for the exploration of the external reality, as it is conceived and interpreted by each actor and each acting group. The free, safe and creative action in the personal play eloquently reveals the actor's attitudes, values and not least internal conflicts. Any such selective representation of external reality utterly facilitates the development of a fruitful intercultural conversation among participants and groups of participants. And this is because the joint action, the compliance to the rules of the play with the aim of a common achievement, as well as the reflection over the collective fictional experience, makes it easier for the participants to step into each other's shoes, to consequently gain a fresh perspective on reality and to overcome their prejudices and fears towards the unfamiliar (see $\Lambda \varepsilon v \alpha x^{\prime} \alpha \chi \eta \varsigma$ 2012).

Art offers alternative and stimulating pathways of learning and promotes aesthetic knowledge (Langer 1954) which in turn encourages intuitive understanding, hence forming the grounds for the evaluation and realization of our place in the world (Bruner 1979, 1990, Reid 1986). Winnicot (2005) considers art as a "transitional" phenomenon, as a dynamic territory of experience, as an "ego and non-ego experience" where internal and external realities coexist and interrelate. Moreover, the aesthetic illusion (Cattanach 1996, Gombrich 1960) offered by works of art constitutes a distant "otherness" which enables an exploration of the world outside the constraints of tangible realities (Langer 1954). Taking account of the rather telling assumption that these alternative realities are projections of the self externalized through a variety of expressive media, one could conclude that education through the arts promotes an understanding not only of the world, but also of the abilities of the individual him-/herself (Witkin 1974). In the same context, Hentschel's view on aesthetical education through the theatre, is very interesting:

I understand theatre pedagogy as a discipline of aesthetical education. From this point of view, theatre pedagogy is not understood as a collection of pedagogical means or tools that should introduce certain target groups to some desirable behavior or notable matter. In fact, the genuine issue of theatre pedagogy is theatre, its specific materiality and production. Aesthetical education therefore asks which experiences theatre pedagogy can procure for non-professional actors. And, subsequently, which educational effects may be opened through these experiences. Instead of starting with the question of what can be transmitted by the means of theatre (which aims and contents) - and therefore use theatre as a pedagogical instrument - I ask how theatre is produced and what kind of experiences can be won in this process. Pedagogical and social aims are not fully discarded. Yet, in terms of aesthetical education, I argue that they are not to be fixed in advance and in a normative way. Aesthetical

\footnotetext{
pioneering, and now classical, work.

${ }^{11}$ For an interesting account of the dynamic and revolutionary character of art's otherness, see Marcuse 1978.
} 
experience that contains an educating experience is more likely to result from collective theatre work on a concrete subject. (Hentschel 2008)

Best (2012) underlines the unbreakable link between the cognitive and the aesthetic, while Ross (1984), through recognition of three important regions of every school curriculum, namely the academic, the practical and the cultural, emphasises the creative arts as a significant part of the latter, since in his own words: "The arts are important to a child's education because they are a way of knowing in their own right and offer unique access to certain dimensions of human experience" (Ross 1984: ii, our emphasis).

Theatre, indeed one of the most significant forms of art, has become a dynamic means of expression. Its "significant form" (Bell 1914: 4) had already become a social and cultural educational agent with Aeschylus, Sophocles and Euripides, the three major tragic poets of Greek Antiquity. The ancient Greek spirit, condensed in the language of drama, has been a fundamental inspiration for the development of the finest of European and international culture.

\section{Programmatic Texts of European and International Organisations}

The research proposals that we suggest below demand that we initially focus on the propositional texts of the European Union and of various international organizations. The main aim of our exploration was to record the philosophy, the principles and the priorities put forward in these texts which center around three basic areas: i) the place and the contribution of the arts in the context of an international cooperation regarding issues concerned with education and information, ii) the promotion of information, creativity and educational research in the service of a more qualitative education, iii) life-long learning and adult education.

More specifically, these texts regarded:

- the "Europe 2020" strategy; ${ }^{12}$

- the European Foundation for Quality Management (EFQM) Excellence Model (2010); ${ }^{13}$

- the European Council conclusions on education and training; ${ }^{14}$

- the strategic framework for European cooperation in education and training "Education and Training 2020" (ET 2020); ${ }^{15}$

\footnotetext{
12 http://ec.europa.eu/resource-efficient-europe/index_en.htm.

13 http://www.efgm.org/en/tabid/132/default.aspx.

14 http://www.consilium.europa.eu/uedocs/cms_data/docs/pressdata/en/ec/120296. pdf.

15 http://europa.eu/legislation_summaries/education_training_youth/general_ framework/ef0016_en.htm.
} 
- the Council conclusions on the role of the Work Plan for Culture 2011-14, ${ }^{16}$ on the role of culture on the implementation of the Europe 2020 strategy $^{17}$ as well as on local and regional development, ${ }^{18}$ on issues of creativity and novelty and on combating poverty and social exclusion; ${ }^{19}$

- the recommendation of the European Parliament and of the Council on the establishment of a European Quality Assurance Reference Framework for Vocational Education and Training; ${ }^{20}$

- the Road Map for Arts Education (UNESCO 2006); ${ }^{21}$

- the Seoul Agenda: Goals for the Development of Arts Education (UNESCO 2010). ${ }^{22}$

In addition to the above, we explored more research findings regarding the basic aspects of lifelong learning ${ }^{23}$ and naturally the role of drama and the arts in education internationally.

\section{Proposed Research Targets}

Having in mind the proposed research programme and the activities its implementation involves, two sets of targets are determined: one regarding individuals and the other drama groups.

Targets regarding individuals:

- The promotion of lifelong learning and of an approach to learning not as something mandatory, but as a process conducive to personal integration and social cohesion; these go hand-in-hand with the exploration of language as a medium not only of communication, but also for the expression of feelings and emotions that shape our identities;

- The promotion of artistic expression and the bolstering of creativity as an agent of personal empowerment cultivating a more critical understanding of the world as well as deconstruction of authoritarian structures paving the path to social transformation;

\footnotetext{
16 http://www.consilium.europa.eu/uedocs/cms_data/docs/pressdata/en/educ/ 122111.pdf.

17 http://eur-lex.europa.eu/LexUriServ/LexUriServ. do?uri=0J:C:2011:175:0001: $0004: \mathrm{EN}: \mathrm{PDF}$.

18 http://eur-lex.europa.eu/LexUriServ/LexUriServ.do?uri=0J:C:2010:135:0015: $0018: \mathrm{EN}: \mathrm{PDF}$.

19 http://www.consilium.europa.eu/uedocs/cms_data/docs/pressdata/en/educ/ 117797.pdf.

20 http://eur-lex.europa.eu/LexUriServ/LexUriServ. do?uri=0J:C:2009:155:0001: $0010: E N: P D F$

21 http://www.unesco.org/new/en/culture/themes/creativity/arts-education.

22 http://www.unesco.org/new/en/culture/themes/creativity/arts-education.

23 http://www.cedefop.europa.eu/EN/bibliographies/lifelong-learningbibliography .aspx. See also Bibliography.
} 
- The promotion of a research procedure that will aid the understanding of the multiple social constructions of meaning and knowledge, aiming in turn at developing new meanings and knowledge;

- The formation of interactive environments fostering mutual understanding and reinforcing communicability, interpersonal relationships and new means of communication;

- The multidimensional development of group members which aids them to gain collective benefits in the context of both local and wider areas, i.e. at a macro- and at a microeconomic level;

- The promotion of communicational and interpersonal skills such as verbal and non-verbal communication, active listening, expressing feelings, giving and receiving feedback;

- The enhancement of negotiation, conflict management, assertiveness and refusal skills;

- The enhancement of empathy, of the ability not only to listen and to understand the other's needs and circumstances, but also to openly express that understanding;

- The promotion of cooperation and teamwork, the development of the ability to respect others peoples' contributions and different lifestyles, coupled with an assessment of one's own abilities and contributions to the group;

- The development of advocacy skills, such as influence and persuasion, networking and motivation;

- The development of abilities concerning decision-making and problemsolving, such as information gathering, evaluation of possible consequences of present actions of oneself and others, becoming able to give alternative solutions to emerging problems;

- The enhancement of critical thinking, which is invaluable for the analytical exploration of values, social norms, beliefs and stereotypes;

- Identifying relevant information and the sources for its collection;

- The elaboration of coping and self-management skills for increasing the internal locus of control (self esteem, confidence-building skills, selfawareness skills including awareness of rights, values, attitudes, strengths and weaknesses, goal setting skills, self evaluation, self-assessment skills);

- The management of anger and of feelings related to grief and anxiety. The development of coping skills for dealing with loss, abuse and trauma; 
- The facilitation of self-expression, the awareness of one's rights, the appreciation of peace, the development of democratic attitudes and the respect to the principles of inter- and multiculturalism;

- The development of emotional involvement, which forms a crucial factor in learning;

- The cultivation of feeling and the development of "feeling ideas" (as put forward by Witkin 1974, 1989), the enhancement of group expressiveness, the improvement of learning and the development of a safe environment with a familiar ambience;

- The development of lateral thinking, of imagination and inventiveness through the creative combination of diverse elements, the creation of new forms of action-taking in the world;

- The holistic development of each group-member's personality and of their potential abilities which, combined with a fruitful interrelation among all group-members, encourages the development of self-confident and socially active citizens.

Targets regarding drama groups, allowing our work to build up from a regional and national Greek level through to a European and an international level:

- The development of the creative abilities of the members of the local community through a line of action that moves from small-scale activities to larger-scale ones;

- The creation of cultural sub-strata at a local level where lifelong learning acquires an aim in the core of democracy, the promotion of polyphony and cultural diversity that contributes to the improvement of the quality of life, the promotion of mutual acceptance, communication, collaboration, and the prevention of behaviours adverse to human dignity;

- The promotion of attempts for the formation of cultural agents in the local community, which in turn contribute to the creation of new job opportunities;

- The strengthening of both vertical and horizontal collaborations between the cultural and other social sectors, of the cooperation between public and private sectors and the community of citizens;

- The establishment of a cultural tourism project raising awareness on the inescapable necessity of our connection with and the protection of the natural environment and the cultural heritage of Greece, on the necessity of rediscovering the lifestyle of country living and the old means of support, honouring the past and recognizing its significance for the future; 
- The creative and fertile cooperation between universities and local bodies such as city councils, cultural associations, social institutions, etc.;

- The dissemination of the research implications for Europe as well as the promotion of the collaboration between Greek and European universities and other educational and cultural bodies, so as to encourage intercultural exchanges;

- The development of cultural activities which will focus on the local particularities and seek the participation of citizens as well as their encouragement to take political and cultural actions;

- The promotion of mobility among researchers and creators/artists, as well as the encouragement of European citizens to understand each other's civilizations through the exchange of experiences and skills, both during the planning phase and during the dissemination of the programme abroad.

\section{Suggested Research Actions}

\subsection{Research Objectives}

The methodological action we propose for the suggested pieces of research is concerned with the role and effectiveness of educational drama in a range of social and cultural applications, such as in schools, museums, geriatric institutions, prisons, local authority cultural units, mental health institutions, playgrounds, social gatherings or galleries. This multiplicity of interventions requires the implementation of a wide variety of educational drama strategies such as psychokinetic games, role games, simulation games, physical theatre, free and structured improvisations, fairytale narrations, puppet theatre and shadow theatre. These dramatic forms can very well combine with other forms of aesthetic understanding and expression, such as plastic arts, music and dance.

\subsection{Suggested Methodological Approaches}

Our research recommendations can be grouped into two basic categories: (1) Basic Research, during which new insights are produced regarding the basic causes of various phenomena and events, and (2) Experimental Development, during which new knowledge and skills for its use are acquired and existing knowledge is recombined for the production of novel work. ${ }^{24}$

24 See: Community Framework for state aid for research and development and innovation, EU 2006 C 323/01 (in: http://eur-lex.europa.eu/LexUriServ/LexUriServ.do?uri=0J:C: 2006:323:0001:0026:EN:PDF) and General block exemption Regulation 800/2008/EC, EU 2008 L 214/3 (in: http://eur-lex. europa. eu/LexUriServ/LexUriServ. do?uri=0J: L: 2008:214: 0003:0047:EN:PDE). 
The recommended pieces of research can be carried out in three separate and yet interrelated methodological units. The first unit involves a discussion of the research structure; decisions are met on the general framework of the research with regard to the research subjects, the research fellows and assistants, the material to be utilized, and finally the style and the qualitative characteristics of the research target group. During the second unit, the educational and theatropedagogical methods employed for the materialization of the programme are studied, estimated, and clarified. The third unit involves an analysis of the programme outcomes, of the knowledge and skills acquired by all target groups.

Taking into account the European Quality Assurance in Vocational Education and Training ${ }^{25}$ framework, we can suggest the following methodological steps: 1. Planning, 2. Implementation, 3. Assessment, 4. Evaluation and 5. Review.

The suggested methodology for the materialization of our research recommendations is mainly based on the qualitative paradigm, while allowing the parallel implementation of quantitative methodological tools. Due to the idiosyncratic character of the research field, we recommend that the research be carried out according to scientifically flexible and pre-organised research plans using quantitative data, statistical generalizations and mixed methodologies.

In our suggested pieces of social research, the approaches that bear a critical significance are those of action research and case-study $r$ esearch. These two methodological procedures can also be greatly enhanced by the Grounded Theory Method, ${ }^{26}$ producing insights that could provide the field with a plethora of creativity- and novelty-promoting techniques such as brainstorming, nominal group approaches, focus groups, the Delphi technique and its variations, etc.

Moreover, the very techniques of educational drama can be considered as research approaches in themselves. These involve games of telephone conversations and interviews-in-role, hot seat, conscience alley and various role-plays. In some pieces of research we suggest the use of direct observation, interviews, questionnaires and other documents. Whenever written communication is involved, we stress the necessity for a discourse analysis of the exchanged mail messages among participants, of the content of their kept diaries and their life-journals. Life narratives can also serve as an excellent and flexible m ethodological t ool, a s a m edium through which can bring to the surface the complexities of the participants' feelings and subjectivities. More invaluable data can be brought into the bargain through the use of pictures, life charts, sound and video recordings which can be analysed by the participants themselves.

Through the suggested research procedures we aspire not only to reach conclusions concerning the matters at hand, but we also aim at acquainting the participants with the methodological thinking and knowledge that can greatly enhance future research projects of their own.

\footnotetext{
25 See http://www. eqavet.eu/gns/home.aspx.

${ }^{26}$ For the important aspects of the Grounded Theory Method, see these essential books: Glaser Strauss 1967, Strauss 1987, Strauss Corbin 1990.
} 
Finally, the meta-analysis of the pieces of research carried out by each research group can lead to general and more specific conclusions and set new insights and dimensions leading to the expansion of existing theories.

\subsection{Proposed Actions}

The actions of this programme aim basically at the development of a cooperation among different social groups. The social groups on which the research is mainly focused are elderly people, prisoners, museum educators, primary education teachers, students of drama departments in national Greek universities, and citizens in local communities.

In this section we set out the programme's actions which involve the steps of planning, realization, quantitative assessment, evaluation and review.

ACTION 1: "Educational Drama and Social Bodies"

- Laboratory with elderly people: story development and small improvisatory dramas;

- Laboratory with prison convicts: theatrical laboratory, development of social dramas and discussion thereof, analysis of solidified personal identities through the techniques of educational drama;

- Educational drama laboratories in cultural sites: dramatic activity taking place in archaeological and cultural museums, public galleries and libraries;

- Research: research groups recording and assessing the work taking place at cultural venues (e.g. museums) through questionnaires and semi-structured interviews;

- Conference on themes concerning the influence of educational drama on social life;

- Publication of conference proceedings;

- Work visits in European universities for the dissemination of the research implications of the first phase of the programme;

- Creation of a web site for the programme.

ACTION 2: "Narrative and Social Bodies"

Phase A

- Seminars on narration and storytelling presented by storytelling specialists;

- Narration of fairytales: Lectures and workshops on the techniques promoting narrative ability; 
- Life narratives: Workshops on the techniques of transforming oral narratives to theatrical speech;

- A series of personal pieces of research in these social arenas carried out by each member based on open-structured interviews with guidance by the research group;

- Symposium on research completion about narrative procedures and skills;

- Publication of a leaflet presenting the process of the "Narration Group" and the implications of the research in public places;

- Publication of a book containing a full presentation of the research and all its findings;

- Conference presentations of all research findings on narration and storytelling.

Phase B

- Fairytale narrations by elderly women in villages, and development of workshops with senior citizens;

- Life narrations by elderly women in villages, and development of workshops with senior citizens;

- Life narrations by convicts in prisons, development of fairytales and workshops with convicts in rural prisons;

- Theatrical presentation of fairytales and the stories of prison convicts by the members of the research group, with the convicts being the audience;

- Improvisational dramas or theatrical performances of the convict fairytales and life stories by the members of the "Narration Group" in public places such as parks, museums and theatres, which will be taking place with the full consent of the convicts;

- Presentation of the research results "Life Narrations of Prison Convicts" at a national conference;

- Presentation of the research results "Life Narrations of Elderly Women" at a national conference;

- Articles on these life narrations in local and national press, TV- and radio presentations;

- Presentation of a programme entitled "Life narrations of elderly women and prison convicts" in schools and other educational bodies; 
- Work visits in European universities for the dissemination of Action 2, involving the organization of laboratories with students and representatives of social bodies.

ACTION 3: "Puppet Theatre"

- Development of a Research Centre for the Art of Puppetry. The use of certain municipal places will be yielded by local authorities to researchers and artists in order for them to carry out a wide-ranging research on the performing arts of puppetry. The collaboration of schools, universities and local cultural groups will be enriching the research programme with a multidimensional character. The art of puppetry will be historically analysed in regard to its role in the education of young children. We will also be examining parameters of pupils with special needs regarding their social learning, self-awareness, self-provision and self-assistance, and of adolescents regarding their creative access to the curriculum. We will be paying particular emphasis on the positive effects of the use of puppetry on personal and social problems of children and adolescents, showing them how to deal with dangers such as drugs, alcoholism, HIV, school violence, divorce or death. Finally, the researchers will focus on the therapeutic dimension of the art of puppetry.

Secondary Activities:

- Creation of a sign and posters;

- Organization of a national conference on the cognitive, developmental, social as well as on the psychological and therapeutic dimensions of the art of puppetry;

- Organization of a series of three-day conferences dedicated to the art of puppetry with the collaboration of eminent Greek and foreign researchers;

- Organization of a ten-day summer camp dedicated to the art of puppetry where famous puppet players and theatre educators will be invited;

- A puppet-theatre festival will be held at the end of the camping period, where campers and specialists will perform their puppet shows;

- Formation of a joint working group of citizens and students entitled "Pup-

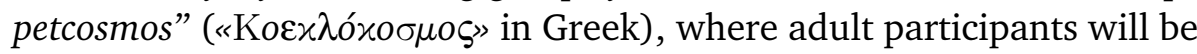
trained in the creation and animation of puppets as an effective means of boosting their careers; the group members will be meeting once every twenty days for three hours per day and for a total period of three years; the working group will always be open for new registrations; 
- Applications: Every "Puppetcosmos" participant will be applying puppetry techniques to their work routines, monitoring all along their performance for aim attainment, and afterwards assessing their own results with the guidance of the researcher group and the guest specialists;

- A course of action research where the head researcher will organize the collected data from all actions of the working group;

- Publication of a book containing the findings of all "Puppetcosmos" participants;

- Exhibition of the constructed puppets and the construction materials by the participants in public places;

- Puppet shows by the participants in public places and on television channels;

- Conference presentations of the whole body of the research on the art of puppetry by the researcher group, who will offer suggestions for further research on the field;

- Work visits to European universities for the dissemination of research implications of Action 3 of the programme;

- Organization of a library containing the puppet theatre plays written by research groups from all over the world;

- Construction of a website dedicated to the art of puppetry where the sum total of the research work will be exhibited, offering opportunities for interactive information sharing, forum discussions, comment- and article uploads, presentations of studies, performances and workshops by researchers, artists and students from all over the world.

ACTION 4: "School for Immigrants"

The implementation of this action will begin from schools on university premises or other public places where the Greek language is already being taught to immigrant or repatriated pupils with the aid of educational drama techniques, where their creativity is fostered through the use of images, puppetry, the plastic arts, improvisational dramas, songs and dances.

A one-year course which could be scheduled to be carried out with one three-hour class every Sunday afternoon, followed by two one-year courses aimed to be organised in response to the immigrant students' interest.

The action will involve the use of writing- and diary-in-role as well as improvisational dialogues, the writing of theatre plays, the giving of puppetand shadow-theatre performances and the publication of a newspaper.

The teaching staff will be composed of pensioned and unemployed teachers (properly trained) and by students who have successfully attended an intensive course on language teaching.

Secondary Activities: 
- Fast-paced training of the staff on language teaching through art by specialists (university teachers and artists);

- Development of educational material for language teaching through art;

- A one-year action research programme for the collection of varied data;

- Presentation of the results of the action research programme at a national conference offering also suggestions for future research;

- Creation of a video library containing footage of simple dialogues, narratives, puppet shows, advertisements and other material facilitating the learning of the Greek language in a playful and non-constrained way;

- Presentation of videos made by immigrants with the assistance of video artists and film makers;

- Creation of a library with children's books and simplified texts;

- Expansion of Greek language teaching in prisons, employing trained educators from the School for Immigrants.

ACTION 5: "Lets Go Theatre"

- Establishment of study groups of theatrical performances and setting up of weekly workshops. Famous theatre companies will be invited in Greece, so that students and citizens of local communities will be given the opportunity to attend selected professional theatre performances. These performances will be concluded with discussions and semi-structured research interviews with the actors and the directors themselves, who will also be giving lectures and organizing workshops, the transcripts of all of which will be uploaded on a website.

ACTION 6: "School of Tourism"

- Professional Greek tourist agents will be initiated in the techniques of educational drama. We will be giving them the opportunity to attend theatrical workshops and to become familiar with the process of lifelong learning, so that their professional abilities become enhanced, including their communicative and problem-solving skills, their management, planning and reviewing skills. Our research team will record their progress and write case studies, and eventually present these findings at an international conference on the role of drama in education and lifelong learning. 


\section{Concluding Note}

In the present work we have attempted to succinctly present the educational potential of drama and theatre, as well as the actions we intend to undertake in various social, cultural and educational milieus to unlock as much as possible of this potential. We have used theatropedagogical and social sciences research findings, taking into consideration the basic programmatic views of European and international bodies on culture, art, innovation and lifelong learning.

We have presented a good number of interdisciplinary projects and actions we are working on, which focus on the creative interchange among diverse cultures and people through drama and theatre, an interchange that has valuable and life-changing lessons to offer to all participants.

An article of this length could not do justice to all aspects of drama, theatre and art which are constantly gaining momentum on all levels of standard and occupational education. The following bibliographical references offer sufficient justification for their powerful influence in our lives and their impressively growing importance in education and society at large.

\section{Bibliography}

Abbs, Peter (1979): Reclamations: Essays on Culture, Mass-Culture and the Curriculum. London: Heinemann

Abbs, Peter (2003): Against the Flow: Education, the arts, and postmodern culture. London: Routledge-Falmer.

Adigüzel, Ömer (2008): The Recent History of Creative Drama in Education in Turkey. 6th Athens International Theatre/Drama and Education Conference, March 30, 2008. In: Creative Drama Journal 1/5, 29-49.

Balfour, Michael St Clair (2006): Drama as Social Intervention. In: http://hdl. handle. net/10072/12646 (last accessed December 22, 2012)

Bell, Clive (1914): Art. New York: Frederick Stoke Publishers

Best, David (2012): The Rationality of Feeling: Learning From the Arts. London: Routledge

Boal, Augusto (1993): Theatre of the Oppressed. New York: Theatre Communications Group

Boal, Augusto (1996): Politics, Education and Change. In: O'Toole, J. \& Daneman, K. (eds.). Drama, Culture and Empowerment. The IDEA Dialogues. Brisbane: IDEA Publications, 47-52

Bolton, Gavin (1982): Drama as Learning, as Art and as Aesthetic Experience. In: Ross, Malcolm (ed.). The Development of the Aesthetic Experience. London: Pergamon, 136-147

Bruner, Jerome (1979): On Knowing: Essays for the Left Hand. Cambridge, MA: Belknap Press of Harvard University Press 
Bruner, Jerome (1990): Acts of Meaning: Four Lectures on Mind and Culture (Jerusalem-Harvard Lectures). Cambridge: Harvard University Press

Bruner, Jerome (1996): The Culture of Education. Cambridge: Harvard University Press

Cattanach, Ann (1996): Drama for People with Special Needs. London: A\&C Black

Coleridge, Samuel Taylor (1907): Biographia Literaria (Vol. II). Oxford: Clarendon Press

Doyle, Clar (1993): Raising Curtains in Education: Drama as a Site for Critical Pedagogy. London: Bergin \& Garvey

Fines, John; Verrier, Raymond (1974): The Drama of History: An Experiment in Co-operative Teaching. London: New University Education

Fischer-Lichte, Erika (2008): The Transformative Power of Performance: A New Aesthetic (Translator: S. I. Jain). London: Routledge

Glaser, Barney G.; Strauss, Anselm L. (1967): The Discovery of Grounded Theory: Strategies for Qualitative Research. New York: Aldine

Goleman, Daniel (2004): Emotional Intelligence - Why It Can Matter More Than IQ \& Working with Emotional Intelligence. New York: Penguin Group

Gombrich, Ernst Hans Josef (1960): Art and Illusion. A Study in the Psychology of Pictorial Representation. London: Phaidon

Hentschel, Ulrike (2008): The So-Called Real. Playing With Reality in Theatre And Theatre Pedagogy. Speech given in Warsaw on October 4th, 2008.

http://www.udk-berlin.de/sites/theaterpaedagogik/content/e348/ e111003/e111004/infoboxContent111008/Theso-

CalledReal_ger.pdf?preview=preview (last accessed October 2, 2013)

Langer, Susanne (1954): Feeling and Form. London: Routledge

Lehmann, Hans-Thies (2006): Postdramatic Theatre (Translator: K. Jürs-Munby). London: Routledge

Lévi-Strauss, Claude (1963): Structural Anthropology. New York: Basic Books

Marcuse, Herbert (1978): The Aesthetic Dimension. New York: Beacon Press

O'Toole, John (1992): The Process of Drama. London: Routledge

O'Toole, John; Donelan, Kate (eds.) (1996): Drama, Culture and Empowerment. The IDEA Dialogues. Brisbane: IDEA Publications

Olson, David R.; Torrance, Nancy (eds.) (1999): The Handbook of Education and Human Development: New Models of Learning, Teaching and Schooling. Oxford: Wiley-Blackwell

Reid, Louis Arnaud (1986): Ways of Understanding and Education. London: Heinemann

Ross, Malcolm (1978): The Creative Arts. London: Heinemann

Ross, Malcolm (1984): The Aesthetic Impulse. London: Pergamon

Scheclmer, Richard (1988): Performance Theory. London: Routledge 
Schiller, Friedrich (2004): On the Aesthetic Education of Man (Translator: Reginald Snell). New York: Dover Publications

Slade, Peter (1953): Child Drama . London: London University Press

Strauss, Anselm L. (1987): Qualitative analysis for social scientists. Cambridge: Cambridge University Press

Strauss, Anselm L.; Corbin, Juliet (1990): Basics of Qualitative Research. Grounded Theory. Procedures and Techniques. Thousand Oaks, CA: Sage

Taylor, Philip (2000): The Drama Classroom: Action, Reflection, Transformation. London: Routledge-Falmer

Turner, Victor Witter (1974): Dramas, Fields and Metaphors. Symbolic Action in Human Society. New York: Cornell University Press

Turner, Victor Witter (1978): The Ritual Process. Harmonsworth: Penguin

UNESCO (2006): The Road Map for Arts Education. PDF file in: http://www . unesco.org/new/en/culture/themes/creativity/artseducation (last accessed October 2, 2013)

UNESCO (2010): The Seoul Agenda: Goals for the Development of Arts Education. PDF file in:

http://www. unesco.org/new/en/culture/themes/creativity/artseducation (last accessed October 2, 2013)

Vygotsky, Lev Semyonovich (1978): Mind in Society: The Development of Higher Psychological Processes. Cambridge: Harvard University Press

Vygotsky, Lev Semyonovich (2012): Thought and Language. Revised and expanded edition. Edited and translated by Eugenia Hanfmann, Gertrude Vakar, and Alex Kozulin. Cambridge, MA: MIT Press

Winnicott, Donald Woods (1992): Through Paediatrics to Psycho-Analysis: Collected Papers. New York: Brunner-Routledge

Winnicott, Donald Woods (2005): Playing and Reality. London: Routledge Witkin, Robert W. (1974): The Intelligence of Feeling. London: Heinemann

Witkin, Robert W. (1989): Expressivist Theories of Art and Ideologies of Arts Education. In: Ross, Malcolm (ed). The Claims of Feeling. London: Falmer, 24-37

Pammenter, David \& Mavrocordatos, Alex (2003): Workshop in Athens, on

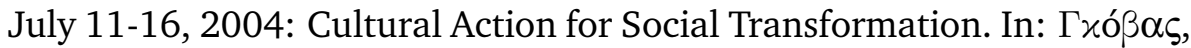

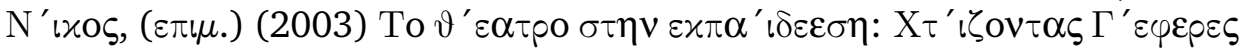
[Govas, Nikos (ed). Drama in Education: Bridging the Gaps], 129-136.

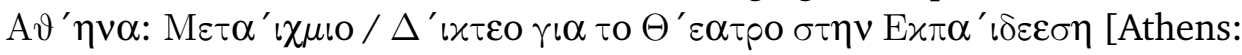
Metechmio / Hellenic Theatre/Drama \& Education Network]

Cassirer, Ernst (2010): Versuch über den Menschen: Einführung in eine Philosophie der Kultur. Hamburg: Felix Meiner Verlag

Domkowsky, Romi (2011): Theaterspielen - und seine Wirkung. (Doktorarbeit). Berlin: Universität der Künste Berlin 
(http://opus4.kobv.de/opus4-udk/frontdoor/index/index/docId/25) (last accessed October 2, 2013)

Dörger, Dagmar; Nickel, Hans-Wolfgang (2005): Spiel- und Theaterpädagogik studieren. Berlin u.a.: Schibri

Fischer-Lichte, Erika (1999): Geschichte des Dramas I. Von der Antike bis zur deutschen Klassik. Stuttgart: UTB

Fuchs, Max (1999): Mensch und Kultur. Anthropologische Grundlagen von Kulturarbeit und Kulturpolitik. Wiesbaden: Westdeutscher Verlag

Fuchs, Max (2011): Die Macht der Symbole. Ein Versuch über Kultur, Medien und Subjektivität. München: Herbert Utz

Hentschel, Ulrike (2010): Theaterspielen als ästhetische Bildung. Über einen Beitrag produktiven künstlerischen Gestaltens zur Selbstbildung. Berlin u.a.: Schibri

Koch, Gerd (1998): Lernen mit Bert Brecht. Bertolt Brechts politisch-kulturelle Pädagogik. Frankfurt/M.: Brandes \& Apsel

Koch, Gerd (2012): Theater: autonom und sozial. In: Scenario VI/1, 10-26.

Lenakakis, Antonios (2004): Paedagogus Ludens. Erweiterte

Handlungskompetenz von Lehrer(inne)n durch Spiel- und Theaterpädagogik.

Berlin u.a.: Schibri

Pinkert, Ute (2005): Transformationen des Alltags. Transformationen der Berliner Lehrstückpraxis und Live Art bei Forced Entertainment. Modelle, Konzepte und Verfahren kultureller Bildung. Berlin u.a.: Schibri

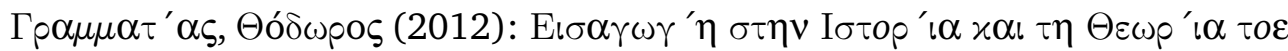
$\Theta \varepsilon$ ' $\alpha$ тров [Grammatas, Theodoros. Introduction to the History and Theory of Theatre]. A $\vartheta^{\prime} \eta \nu \alpha, \mathrm{E} \xi^{\prime} \alpha \nu \tau \alpha \varsigma$

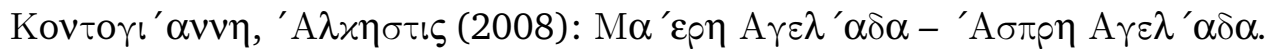

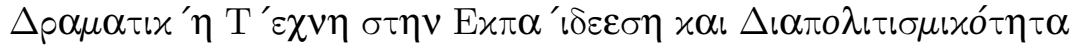
[Kondoyianni, Alkistis. Black Cow - White Cow. Drama and Intercultural

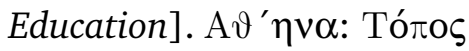

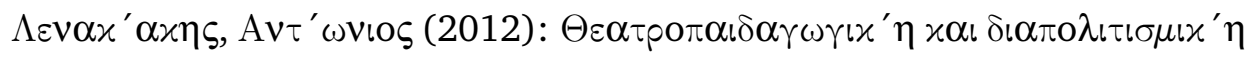

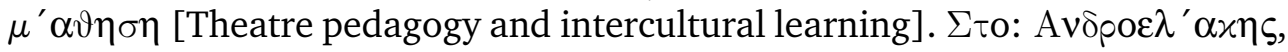

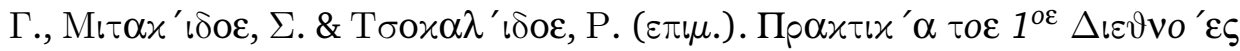

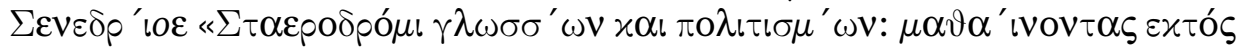
$\sigma \chi 0 \lambda \varepsilon^{\prime}$ ' овє» [In: Androulakis, G.; Mitakidou, S.; Tsokalidou, R. (eds.). Proceedings of the 1st International Conference "Crossroad of languages and cultures: learning beyond the classroom"], 114-128. $\mu^{\prime} \alpha \delta \alpha$ По $\lambda$ ' $\varepsilon \delta \rho \circ \mu \mathrm{o}$,

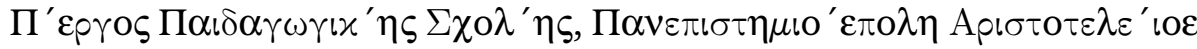
$\Pi \alpha v \varepsilon \pi \iota \tau \tau \mu^{\prime}$ 'о $\Theta \varepsilon \sigma \sigma \alpha \lambda \circ \nu^{\prime}\llcorner\varkappa \eta \varsigma$ [Polydromo Group, Faculty of Education, Aristotle University of Thessaloniki]

English -

English-Greek — 
Alkistis Kondoyianni, Antonis Lenakakis, Nikos Tsiotsos Intercultural and lifelong learning based on educational drama ${ }^{1}$
Scenario Volume 2013 · Issue 2

German -

Greek - 